\title{
Stability assessment of the slopes and side-hills with account of the excess pressure in the pore liquid
}

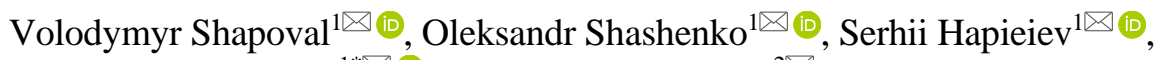 \\ Oleksii Khalymendyk ${ }^{1 * \otimes(\mathbb{D}, \text { Volodymyr Andrieiev }}{ }^{2 \otimes}$ \\ ${ }^{1}$ Dnipro University of Technology, Dnipro, 49005, Ukraine \\ ${ }^{2}$ Dnipro National University of Railway Transport named after Academician V. Lazaryan, Dnipro, 49010, Ukraine \\ *Corresponding author: e-mail khalymendyk.o.v@nmu.one, tel.+380509054262
}

\begin{abstract}
Purpose. The strength criteria substantiation of water-saturated soils and mine rocks, which make it possible to obtain the analytical solutions necessary for determining the stability of water-flooded soil slopes and side-hills.

Methods. The methods are applied of analysis and generalization of the theoretical and numerical experimental studies results. The rocks and soils characteristics are taken into account: specific cohesion $c$, internal friction angle $\varphi$, compressive strength $R_{c}$ and tensile strength $R_{p}$ of the rock, as well as the bulk density. The load $q$ was imposed to the water-saturated seam roof from the overlying mine rock or soil seams, the weight of equipment or structures located on the surface. It was accepted that the seam is saturated with water (gas) with the excess pressure $P$. A point on the mine working surface (or vertical slope surface), located at a depth $z$ is considered. It is determined at which ratio of $q, P$ and $z$ parameters the soil or rock seam will be destroyed. The problem solution is based on the Mohr-Coulomb strength criterion.
\end{abstract}

Findings. The strengths of water-saturated rock and water-free rock are compared. The ratios have been obtained that make possible to determine the critical load on the daylight surface of water-saturated and water-free vertical slopes, side-hills, trenches and foundation pits, as well as various mine workings in soil bases and mine rocks. The analytical solution has been obtained, which makes it possible to determine a value of the critical pressure on the water-flooded vertical surfaces and soil slopes. The generalization has been made of a certain one-dimensional Mohr-Coulomb strength condition for a water-saturated base characterized by the strength characteristics $c$ and $\varphi$ for the dimensional case.

Originality. It has been theoretically proved that for any pore pressure value in the water-saturated mine rock (or soil) their strength will be less than in their water-free state. New solutions have been formulated for determining the critical height of a water-saturated vertical soil slope or the wall in the vertical mine working.

Practical implications. The obtained results make it possible to solve the practical engineering problems on determining the stability of water-saturated slopes and side-hills with a load-free daylight surface, therewith, taking into account the weight of the equipment, stored material and the stability of vertical walls of water-saturated seams of open-cut mine workings.

Keywords: strength criterion, pore liquid, pore gas, pressure, slope stability, water-saturated soil, friction angle

\section{Introduction}

Coal is our most abundant fossil fuel. There is still enough coal underground in Ukraine [1], [2] and foreign countries [3]-[6]. During mining occurs rock pressure [7][10]. According to modern scientific data, the presence in the soil and mine rock of excess pressure in the pore liquid leads to such effects [11]-[17]:

1. There is a significant change in the stress-strain state of the rock (or soil) massif.

2. Even with a constant in time external load, deformations and stresses within the soil (rock) massif and at its boundaries are changed in time. This phenomenon is condi- tioned by the property of the pore liquid viscosity and, as a consequence, the process of its migration stretched over time in the pores of the soil (rock) stratum under the influence of excess pressure. This phenomenon determines the difference between water-saturated and water-free soils and mine rocks.

3. There is also a difference in the behaviour of watersaturated and water-free soils and mine rocks under the influence of an external dynamic load. In this case, in comparison with water-free soils and mine rocks, there is a distortion of eigen-frequencies, vibration amplitudes and stresses acting in soil (rock) massifs. 
4. In our opinion, the most important is the fact that the presence in the soil and mine rock of excess pressure in the pore liquid reduces the strength of the soil slopes, side-hills and mine workings.

Therefore, it is of considerable interest the determination of the critical values of such parameters as the pressure in a pore liquid or gas, the depth at which the rock massif destruction is possible (Fig. 1) in the conditions of water and gas saturation of mine rocks.

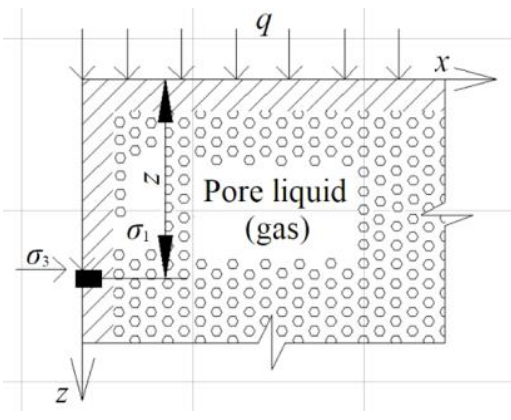

Figure 1. The scheme for the determination of the critical pressure $P$, critical load $q$ onto the roof of the watersaturated or gas-saturated soil (rock) seam

Up to date, many scientists and research teams are involved in such issues [18]-[21], however, the issue has not been sufficiently studied from this point of view [22]-[26]. Thus, Institute of Geotechnical Mechanics named by N. Poljakov of National Academy of Sciences of Ukraine (Dnipro, Ukraine) employees of Ukraine has performed the studies related to gas-dynamic assessment of coal and rock massif [27]-[28], and particular attention is paid to methane release into the face of underground mine workings, to the gas pressure in the stratum, and other factors [29]-[31]. The physical and chemical processes occurring in the rock massif are quite well presented in the works of V.V. Soboliev and of the teams working under his leadership [32]-[34] at the Dnipro University of Technology (Ukraine).

Thus, the purpose of the work is to substantiate the strength criteria for the water-saturated soils and mine rocks, which make it possible to obtain analytical solutions necessary for determining the stability of water-flooded soil slopes and vertical mine workings.

\section{Materials and methods}

The research task has been formulated as follows:

1. The strength characteristics are known of the soil or mine rock (specific cohesion $c$ and internal friction angle $\varphi$ ) or (compressive strength $R_{c}$ and tensile strength $R_{p}$ of the rock) [35], [36].

2 . The soil bulk density (rock) $\gamma$ is known.

3 . The load $q$ was imposed to the roof of the watersaturated seam (this can be a load from overlying mine rock or soil seams, the weight of equipment or structures located on the surface of the vertical slope, etc.).

4. The soil (rock) seam is saturated with water (gas), the excess pressure in which is equal to $P$.

5. A point on the surface of the mine working (or vertical slope), located at a depth $z$ is considered.

It is necessary to determine, at which ratio of $q, P$ and $z$ parameters the rock (or soil) seam will be destroyed.
To solve the problem, we use the Mohr-Coulomb strength criterion [37]:

$$
\tau \leq(\sigma-P) \operatorname{tg}(\varphi)+c,
$$

where:

$\tau$ - shear stress;

$\sigma$ - the same, but normal stress.

At the same time, we take into account that in the soils and mine rocks mechanics, the compressive normal stresses should be considered with the plus sign, and the tensile normal stresses should be taken with the minus sign.

In addition, we take into account that, according to the Mohr-Coulomb strength criterion, other factors being equal, the destruction of soil, mine rock and coal occurs when the maximum and minimum normal stresses $\sigma_{1}$ and $\sigma_{3}$ reach a certain critical combination. Herewith, the principal normal stress $\sigma_{2}$ does not almost influence the strength.

In order to reduce the one-dimensional Mohr-Coulomb condition (1) to the dimensional case with the principal normal stresses $\sigma_{1}$ and $\sigma_{3}$ in accordance with the information and data presented in the works of V.A Florin [37], [38], we set into (1):

$$
\left.\begin{array}{c}
\tau=\tau_{m} \cdot \cos (\varphi) ; \\
\sigma=\sigma_{m}-\tau_{m} \cdot \sin (\varphi) ; \\
\tau_{m}=\frac{\sigma_{1}-\sigma_{3}}{2} ; \\
\sigma_{m}=\frac{\sigma_{1}+\sigma_{3}}{2}
\end{array}\right\}
$$

We obtain:

$$
\left.\begin{array}{c}
\frac{\sigma_{1}-\sigma_{3}}{\sigma_{1}+\sigma_{3}-2 P+2 \operatorname{cctg}(\varphi)} \leq \sin (\varphi) \\
\sigma_{1}+\sigma_{3}-2 P+2 \operatorname{cctg}(\varphi) \geq 0 \\
\sigma_{1} \geq \sigma_{2} \geq \sigma_{3}
\end{array}\right\}
$$

Analysis of the expression (3) has allowed us to draw the following conclusions:

1. This expression is different from the well-known in the literature [1], [37], [38] the Mohr-Coulomb strength condition and the presented below ratios (5), by the presence of the " $P$ " summand in the denominator, i.e. pore pressure, taken with a "minus" sign.

2. With an increase in the pore pressure and the positive value of denominator (3), the left part of the upper equation increases. Thus, in this case there is a decrease in the strength of the soil (rock).

3. At significant values of the pore pressure $P$ and the fulfilment of the condition:

$$
\sigma_{1}+\sigma_{3}-2 P+2 \operatorname{cctg}(\varphi)<0,
$$

the strength condition (3) changes to the super-critical area and has not the physical meaning.

4. If to set in (3) the pore pressure equal to zero (i.e. $P=0$ ), we will obtain the generally accepted record of the Mohr-Coulomb strength condition: 


$$
\left.\begin{array}{c}
\frac{\sigma_{1}-\sigma_{3}}{\sigma_{1}+\sigma_{3}+2 \operatorname{cctg}(\varphi)} \leq \sin (\varphi) \\
\sigma_{1} \geq \sigma_{2} \geq \sigma_{3} .
\end{array}\right\}
$$

In such a way, the generally accepted record of the MohrCoulomb strength condition (5) is a special case of the obtained solution (3).

5. If in (3) to change the sign before the pore pressure $P$ (i.e., not to inject the liquid or gas into the base, but to pump them out), then the base will be strengthened.

Then, we will compare the strength conditions (3) and (5).

We will divide term-by-term the upper equation (5) by the upper equation (3). Given the fact that the left and right parts of (3) and (5) are greater than zero, we have:

$$
\psi=\frac{\sigma_{1}+\sigma_{3}-2 P+2 \operatorname{cctg}(\varphi)}{\sigma_{1}+\sigma_{3}+2 \operatorname{cctg}(\varphi)} \leq 1 .
$$

Then we will set in (6):

$$
\chi=\frac{2 P}{\sigma_{1}+\sigma_{2}+2 \operatorname{cctg}(\varphi)} .
$$

With account of inequation (7), the second condition (3) and inequation (6) will take the form:

$$
\left.\begin{array}{c}
\psi=1-\chi \leq 1 \\
0 \leq \chi \leq 1
\end{array}\right\}
$$

In such a way, the range of the dimensionless group $\chi$ definition is all the positive numbers on the interval $\chi \in(0.1)$, the range of function $\psi$ values is on the interval $\chi \in(0.1)$ (Fig. 2).

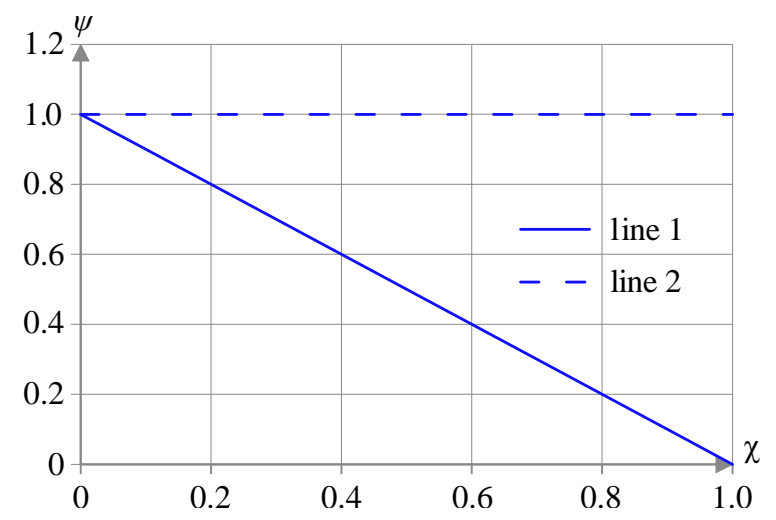

Figure 2. The ranges of definition and values (8) (graphical interpretation): line 1 - the boundary of the limiting condition of water-saturated rock (or soil); line 2 - the same, water-saturated

\section{Results and discussion}

The analysis of dependences presented in Figure 2 made it possible to conclude that at any pore pressure value in the water-saturated mine rock (or soil) their strength will be less than in their water-free state. It should be noted that equation (3) can also be obtained in a simpler way, based upon quite general considerations - Figure 3.

Consider some elementary volume of soil (or rock) to which the principal stresses are applied externally $\sigma_{1}, \sigma_{2}$ and $\sigma_{3}$.

Inside the sample, pressure acting in pore liquid or gas is numerically equal to $P$ (in soil mechanics it is called neutral, Fig. 2).

In accordance with the Pascal's law, this pressure acts in all directions, and its values in all directions are equal to each other.

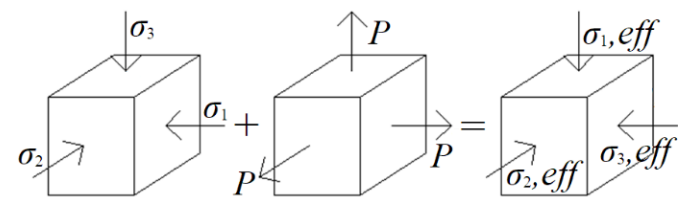

Figure 3. Scheme for the determination of effective stresses in the soil (rock) matrix

Furthermore, in accordance with the principle of K. Terzaghi's moisture capacity, the matrix of the soil (rock) is under the influence of an effective pressure, which is numerically equal to the difference between the principal stresses and the pore pressure P:

$$
\left.\begin{array}{c}
\left|\begin{array}{ccc}
\sigma_{1, \text { eff }} & 0 & 0 \\
0 & \sigma_{2, \text { eff }} & 0 \\
0 & 0 & \sigma_{3, \text { eff }}
\end{array}\right|= \\
=\left|\begin{array}{ccc}
\sigma_{1} & 0 & 0 \\
0 & \sigma_{2} & 0 \\
0 & 0 & \sigma_{3}
\end{array}\right|-\left|\begin{array}{ccc}
P & 0 & 0 \\
0 & P & 0 \\
0 & 0 & P
\end{array}\right| \\
= \\
\left|\begin{array}{ccc}
\sigma_{1}-P & 0 & 0 \\
0 & \sigma_{2}-P & 0 \\
0 & 0 & \sigma_{3}-P
\end{array}\right| \\
\sigma_{1, \text { eff }} \geq \sigma_{2, \text { eff }} \geq \sigma_{3, \text { eff }} ; \\
\sigma_{1}-P \geq \sigma_{2}-P \geq \sigma_{3}-P .
\end{array}\right\}
$$

Here $\sigma_{i, \text { eff }}-$ the effective values of principal stresses.

For the final solution of the problem, we replace in (5) the principal stresses $\sigma_{i}$ by their effective values $\sigma_{i \text {, eff. Thus, }}$ we arrive at the ratios obtained earlier (3).

It should be noted that the same condition of strength (3) for water-saturated soil (mine rock) has been obtained in various ways. This indicates the validity of the result obtained by us.

The strength characteristics $c$ (specific cohesion) and $\varphi$ (internal friction angle) are commonly used in prediction of soil destruction [1], [37]. Thus, in mechanics of mine rocks, their strength at uniaxial compression $R_{c}$ and strength at uniaxial tension $R_{p}$ are used as strength characteristics [38].

According to the data presented in the works of V.A. Florin and work [38], between the compressive strengths $R_{c}$ and tensile strengths $R_{p}$, as well as between the trigonometric functions of the internal friction angle of the mine rock and its specific cohesion the following ratios occur:

$$
\left.\begin{array}{c}
c=\frac{1}{2} \cdot \sqrt{R_{c} \cdot R_{p}} ; \\
\sin (\varphi)=\frac{R_{c}-R_{p}}{R_{c}+R_{p}} ; \\
\cos (\varphi)=\frac{2 \cdot \sqrt{R_{c} \cdot R_{p}}}{R_{c}+R_{p}} ; \\
\operatorname{tg}(\varphi)=\frac{\sin (\varphi)}{\cos (\varphi)}=\frac{R_{c}-R_{p}}{2 \cdot \sqrt{R_{c} \cdot R_{p}}} ; \\
\operatorname{ctg}(\varphi)=\frac{\cos (\varphi)}{\sin (\varphi)}=\frac{2 \cdot \sqrt{R_{c} \cdot R_{p}}}{R_{c}-R_{p}} .
\end{array}\right\}
$$


When substituting the ratios (10) into obtained equation (3), we have:

$$
\begin{gathered}
\frac{\sigma_{1}-\sigma_{3}}{\sigma_{1}+\sigma_{3}-2 P+2 \cdot \frac{R_{c} \cdot R_{p}}{R_{c}-R_{p}}} \leq \frac{R_{c}-R_{p}}{R_{c}+R_{p}} \\
\sigma_{1}+\sigma_{3}-2 P+2 \cdot \frac{R_{c} \cdot R_{p}}{R_{c}-R_{p}} \geq 0 \\
\sigma_{1} \geq \sigma_{2} \geq \sigma_{3}
\end{gathered}
$$

wherefrom, with account of notation $\xi=\frac{R p}{R c}$, we will find:

$$
\begin{aligned}
& \xi=\frac{R_{p}}{R_{c}} ; \\
& \frac{\sigma_{1}-\sigma_{3}}{\sigma_{1}+\sigma_{3}-2 P+2 \cdot R_{c} \cdot \frac{\xi}{1-\xi}} \\
& \sigma_{1}+\sigma_{3}-2 P+2 \cdot R_{c} \cdot \frac{\xi}{1-\xi} \geq 0 ; \\
& \sigma_{1} \geq \sigma_{2} \geq \sigma_{3} .
\end{aligned}
$$

The conditions (11) obtained by us are another form of the record of obtained above Mohr-Coulomb strength condition for water-saturated soil (3), where instead of strength material constants $c$ and $\varphi \varphi$, other material constants were used, such as the compressive strengths $R_{c}$ and tensile strengths $R_{p}$ of the mine rock.

Analysis of the expression (11) has allowed us to draw the following conclusions:

1. The obtained strength condition of water-saturated mine rock (11) is different from the well-known in the literature Mohr-Coulomb strength condition [1], [37], [38] by the presence of the " $P$ " summand in the denominator, i.e. pore pressure, taken with a 'minus' sign and by the strength material constants.

In other words, instead of the strength material constants $c$ and $\varphi$ accepted in (3), other material constants are used in (11), such as the compressive strengths $R_{c}$ and tensile strengths $R_{p}$ of the mine rock.

2 . With an increase in the pore pressure and the positive value of the denominator in the upper inequation (11), there is an increase in its left part. Therefore, in this case, there is a decrease in the strength of the water-saturated mine rock.

3. At significant values of the pore pressure $P$ and the fulfilment of the condition:

$\sigma_{1}+\sigma_{3}-2 P+2 R_{c} \cdot \frac{\xi}{1-\xi} \geq 0$

the strength condition (11) changes to the super-critical area and has not the physical meaning.

4. If to set in (11) the pore pressure equal to zero (i.e. $P=0$ ), we will obtain the record of the Mohr-Coulomb strength condition for water-free mine rock in this form:

$$
\left.\begin{array}{c}
\xi=\frac{R_{p}}{R_{c}} ; \\
\frac{\sigma_{1}-\sigma_{3}}{\sigma_{1}+\sigma_{3}-2 R_{c} \cdot \frac{\xi}{1-\xi}} \leq \frac{1-\xi}{1+\xi} \\
\sigma_{1} \geq \sigma_{2} \geq \sigma_{3} .
\end{array}\right\}
$$

In such a way, the generally accepted record of the MohrCoulomb strength condition (13) is a special case of the obtained solution (3).

5. If in (11) to change the sign before the pore pressure $P$ (i.e., not to inject the liquid or gas into the mine rock, but to pump them out), then there will be the strengthening of the rock massif.

Then, we will compare the strengths of water-saturated rock and water-free rock.

We will divide term-by-term the second equation from above (11) by the second equation from above (13). Given the fact that the left and right parts of (11) and (11) are greater than zero, we have:

$$
\psi_{1}=\frac{1+\sigma_{3}-2 P+2 R_{c} \cdot \frac{\xi}{1-\xi}}{1+\sigma_{3}+2 R_{c} \cdot \frac{\xi}{1-\xi}} \leq 1 .
$$

Then we will set in (14):

$$
\chi_{1}=\frac{2 P}{\sigma_{1}+\sigma_{3}+2 R_{c} \cdot \frac{\xi}{1-\xi}}
$$

With account of (15), the inequation (14) and the third condition from above (11) will take the form:

$$
\begin{gathered}
\psi_{1}=1-\chi_{1} \leq 1 \\
0 \leq \chi_{1} \leq 1
\end{gathered}
$$

In such a way, the range of the dimensionless group $\chi_{1}$ definition is all the positive numbers on the interval $\chi_{1} \epsilon \in$ $(0.1)$, and the range of function $\psi_{1}$ values is on the interval $\psi_{1}$ $\epsilon(0.1)$. Further on, we use the obtained result (3) to solve a number of specific engineering problems of soil mechanics and geotechnical mechanics.

First, we will find the principal normal critical stress $\sigma_{1, c r}$, at which the water-saturated soil seam will be destroyed (Fig. 1).

Assume that the rate of mine working drivage and the permeability coefficient are such that the pore pressure dispersion can be neglected near the wall of mine working. This property is appropriate for over-consolidated clays, coal strata with closed porosity, and also for all soils and mine rocks with a low value of the permeability coefficient [39].

In this case, the horizontal principal stress is equal to zero $\left(\sigma_{3}=0\right)$, so that the strength condition (3) will take the form:

$$
\left.\begin{array}{c}
\frac{\sigma_{1}}{\sigma_{1}-2 P+2 \operatorname{cctg}(\varphi)} \leq \sin (\varphi), \\
\frac{\sigma_{1}-2 \operatorname{cctg}(\varphi)}{2} \leq P .
\end{array}\right\}
$$


Having solved (17), according to the principal stress $\sigma_{1}$, we will finally find:

$$
\left.\begin{array}{c}
\sigma_{1, c r} \geq 2 P-2 \operatorname{cctg}(\varphi), \\
\sigma_{1, c r} \geq \frac{2 c \cos (\varphi)}{1-\sin (\varphi)}-\frac{2 P \sin (\varphi)}{1-\sin (\varphi)}
\end{array}\right\}
$$

To analyse the solution (18) obtained by us, first examine the behaviour of the internal friction angle functions $\varphi$ $f_{1}=\frac{\cos (\varphi)}{1-\sin (\varphi)}$ and $f_{2}=\frac{\sin (\varphi)}{1-\sin (\varphi)}$, which are presented in Figure 4.

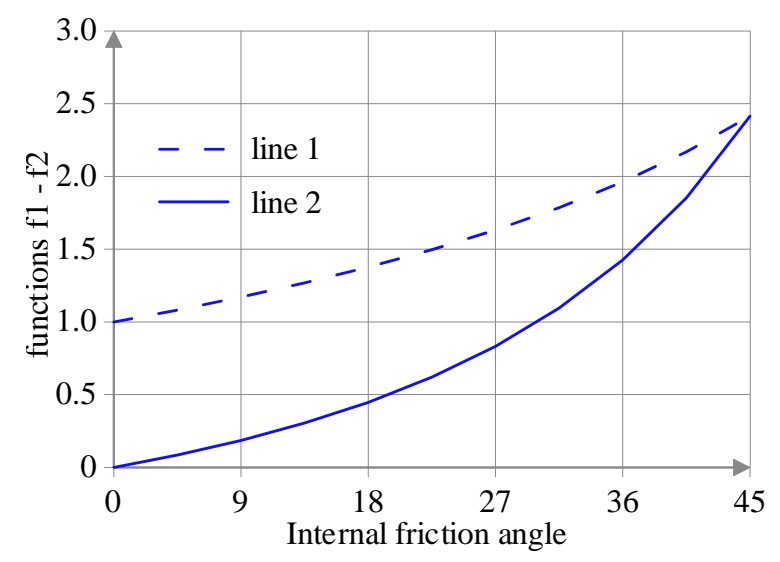

Figure 4. The dependence of functions $f_{1}=\frac{\cos (\varphi)}{1-\sin (\varphi)}$ (line 1) and

$$
f_{2}=\frac{\sin (\varphi)}{1-\sin (\varphi)} \text { (line 2) on the internal friction angle } \varphi
$$

The range of the internal friction angle variation is accepted from those considerations that for absolutely plastic soils and mine rocks (for example, for silts) the internal friction angle $\varphi \approx 0$, and for very hard rocks (granites, diorites) $\varphi=43-45$ degrees [40]-[42].

It follows from the Figure 4, that on the interval of the internal friction angle variation $\varphi \in(0 \ldots 45)$ functions $f_{1}$ and $f_{2}$ increase monotonically, and $f_{1}(\varphi) \geq f_{2}(\varphi)$.

The analysis of inequations (18), with account of the data presented in Figure 4, made it possible to conclude that the critical value of the principal stress $\sigma_{1, c r}$ is greater, if:

- the greater is the specific cohesion $c$ and internal friction angle $\varphi$;

- the pressure value in the pore liquid $P$ is less.

It should also be noted that the inequations (18) do not make sense when the internal friction angle $\varphi$ decreases to zero (i.e., when $\varphi \rightarrow 0$ ), since in this case the pressure in the pore liquid (gas) does not affect the strength of soil (mine rock). This effect is explained by various mechanisms of destruction of ideally-plastic soils (for example, silt), and soils with specific cohesion and internal friction [1]. A similar result we get, when setting into (1) the internal friction angle equal to zero.

Then, we will find the principal normal critical stress $\sigma_{1, c r}$, at which the vertical slope wall in the water-saturated or gas-saturated soil seam will be destroyed (Fig. 1).

Having set into (11) the principal stress $\sigma_{3}=0$ (Fig. 3) and having solved the inequations obtained in this way with account of the principal stress $\sigma_{1}$, we will find:

$$
\begin{gathered}
\xi=\frac{R_{p}}{R_{c}} \\
\sigma_{1} \leq R_{c}-\frac{1-\xi}{\xi} \cdot P \\
\sigma_{1} \geq 2 P-2 R_{c} \cdot \frac{\xi}{1-\xi} \\
\sigma_{1} \geq \sigma_{2} \geq \sigma_{3} .
\end{gathered}
$$

The solution (18) allows us to determine the critical height $q_{c r}$ of a water-saturated vertical soil slope or of the wall in the vertical mine working (Fig. 5).

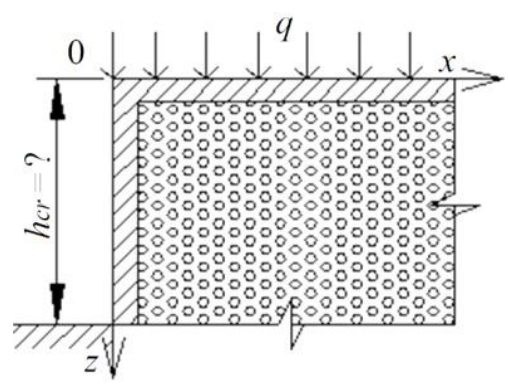

Figure 5. To the determination of the critical height of a watersaturated vertical slope

It follows from the Figure 5, that if the bulk density of the soil is equal to $\gamma$, then at depth of $h_{c r} h_{c r}$ the principal stress $\sigma_{1, c r}$ is equal to:

$\sigma_{1, c r}=q+\gamma h_{c r}$.

When substituting (20) into (18), we will find:

$$
\left.\begin{array}{c}
h_{c r} \geq \frac{2 P-2 \operatorname{cctg}(\varphi)-q}{\gamma}, \\
h_{c r} \geq \frac{2 c \cos (\varphi)}{\gamma[1-\sin (\varphi)]}-\frac{2 P \sin (\varphi)}{\gamma[1-\sin (\varphi)]}-\frac{q}{\gamma} \cdot
\end{array}\right\}
$$

Having set into (21) the pore pressure $P=0$, we will arrive at the well-known formula for determining the critical height of water-free soil slope [37]:

$$
h_{c r} \leq \frac{2 c \cos (\varphi)}{\gamma[1-\sin (\varphi)]}-\frac{q}{\gamma} \text {. }
$$

The obtained ratios (21) make it possible to solve the following engineering problems:

1. The determination of the critical height of water-saturated vertical slopes, side-hills, trenches and foundation pits and, in general, of various mine workings in soil bases and mine rocks.

2 . The determination of the stability of water-saturated vertical slopes, side-hills, trenches and foundation pits and, in general, of various mine workings in soil bases with a surface free from the load (for this we should set into (21) $q=0$ ).

3 . The determination of the critical height of water-free vertical slopes, side-hills, trenches and foundation pits and, in general, of various mine workings in soil bases and mine rocks.

In conclusion, we note that if the water-saturated soil seam in which the mine working is arranged is at a certain depth $H$ below the water-free soil seams, which have the thicknesses $h_{i}$ and bulk densities $\gamma_{i}$, then the parameter $q$ entering the formula (18) should be determined as follows: 
$q=\sum_{i=1}^{n} \gamma_{i} h_{i}$

Here $\gamma_{i}$-bulk density $i$ - of those soil seam; $h_{i}$-its thickness; $n$-number of soil seams. Besides, there is an equation $H=\sum_{i=1}^{n} n_{i}$.

The obtained ratios (18) also make possible to determine the critical load $q_{c r}$ on the daylight surface of a watersaturated vertical soil slope or vertical mine working in the base (Fig. 5). Having substituted (20) into (18) and solving the inequations obtained in this way with respect to the load $q$, we will find:

$$
\left.\begin{array}{c}
q_{c r} \geq 2 P-2 c c t g(\varphi)-\gamma h ; \\
q_{c r} \leq \frac{2 c \cos (\varphi)}{1-\sin (\varphi)}-\frac{2 P \sin (\varphi)}{1-\sin (\varphi)}-\gamma h .
\end{array}\right\} .
$$

The ratios (24) make it possible to solve the following engineering problems:

1. The determination of the critical load on the daylight surface of water-saturated vertical slopes, side-hills, trenches and foundation pits and, in general, of various mine workings in soil bases and mine rocks.

2. The determination of the critical load on the daylight surface of water-free vertical slopes, side-hills, trenches and foundation pits and, in general, of various mine workings in soil bases and mine rocks (for this we should set into (24) $q=0$.

3 . The determination of the critical depth at which an arrangement of the mine working with vertical walls is possible in a water-saturated soil (or rock) seam, above which there are soil (or rock) seams with bulk densities $\gamma_{i}$. In this case, the inequations (24) should be represented in the form:

$$
\left.\begin{array}{c}
H_{k r} \geq \frac{2 P-2 c \operatorname{tg}(\varphi)-\gamma h}{\sum_{i=1}^{n} \gamma_{i}} \\
H_{k r} \leq \frac{2 c \cdot \cos (\varphi)}{[1-\sin (\varphi)] \sum_{i=1}^{n} \gamma_{i}}- \\
-\frac{2 P \sin (\varphi)}{[1-\sin (\varphi)] \sum_{i=1}^{n} \gamma_{i}}-\frac{\sum_{i=1}^{n} \gamma_{i}}{i=1}
\end{array}\right\} .
$$

When solving the practical problems for construction of foundation and mines, the problem often arises of the critical pressure determination in the pore liquid or gas in the base, in which it is necessary to arrange the mine working with vertical walls. Therein, when strengthening the bases using the high-pressure injection method [37], it is also important to know the critical pressure value near the underground mine workings, utility systems and other structures.

To determine the critical value in a pore liquid (gas), we will solve (17) with respect to the pore pressure $P$. We have:

$$
\left.\begin{array}{c}
P=\frac{2 c \cos (\varphi)-[1-\sin (\varphi)] \sigma_{1}}{2 \sin (\varphi)} ; \\
P \leq \frac{1}{2}\left[\sigma_{1}+2 \operatorname{cctg}(\varphi)\right] .
\end{array}\right\} .
$$

The least of the pore $P$ values corresponds to the critical value in the pore liquid (gas) in (25). Since for any value of the internal friction angle $\varphi$ there is an inequation $\frac{-[1-\sin (\varphi)]}{2 \sin (\varphi)}<\frac{1}{2}$, then the critical pressure in the pore liquid (gas) $P_{c r}$ is equal:

$$
P_{c r}=\frac{2 c \cdot \cos (\varphi)-[1-\sin (\varphi)] \sigma_{1}}{2 \sin (\varphi)} .
$$

Further on, we adapt the results obtained for the strength material constants $c$ and $\varphi$ (i.e., the specific cohesion and the internal friction angle) to the material constants $R_{c}$ and $R_{p}$ which have been accepted in the mine rock mechanics (i.e., the rock strengths for uniaxial compression and uniaxial tension).

At first, with the use of (19) and (20), we will find the critical height $q_{c r}$ of the water-saturated vertical soil slope or the wall of vertical mine working (Fig. 5). We obtain:

$$
\left.\begin{array}{c}
\xi=\frac{R_{p}}{R_{c}} ; \\
q_{c r} \leq \frac{R_{c}}{\gamma}-\frac{1-\xi}{\gamma \xi} \cdot P-\frac{q}{\gamma} ; \\
q_{c r} \geq \frac{2 P}{\gamma}-2 \cdot \frac{R_{c}}{\gamma} \cdot \frac{\xi}{1-\xi}-\frac{q}{\gamma} \cdot
\end{array}\right\} .
$$

Having set the pore pressure equal to zero in (28), we find the critical height of the water-free mine rock. We obtain:

$$
\left.\begin{array}{c}
\xi=\frac{R_{p}}{R_{c}} ; \\
q_{c r}=\frac{R_{c}}{\gamma}-\frac{q}{\gamma} .
\end{array}\right\}
$$

It can also be noted that formulas (28) and (29) are completely analogous to formulas (21) and (22), respectively. The only difference is in the recording of material constants. The obtained ratios (19) make it possible to determine the critical load $q_{c r}$ on the daylight surface of a water-saturated vertical soil slope or vertical mine working in the base (Fig. 5).

Having substituted (20) into (19) and solving the inequations obtained in this way with respect to the load $q$, we will find:

$$
\left.\begin{array}{c}
\xi=\frac{R_{p}}{R_{c}} ; \\
q_{c r} \leq R_{c}-\frac{1-\xi}{\xi} \cdot P-\gamma h ; \\
q_{c r} \geq 2 P-2 R_{c} \cdot \frac{\xi}{1-\xi}-\gamma h .
\end{array}\right\}
$$

The ratios (30) are completely analogous to (24). The only difference between them is in the material constants. If the thicknesses of the soil seams above the considered point $h_{i}$ and their bulk densities $\gamma_{i}$ are known, the equation (30) makes it possible to determine the critical depth at which the mine working with vertical walls without support can be arranged in the water-saturated rock. By analogy with (25), we have: 


$$
\left.\begin{array}{c}
\xi=\frac{R_{p}}{R_{c}} ; \\
H_{c r} \geq \frac{2 P-2 R_{c} \cdot \frac{\xi}{1-\xi}-\gamma h}{\sum_{c r}^{n} \gamma_{i}} ; \\
H_{i=1}^{n} \gamma_{i}
\end{array}\right\}
$$

To determine the critical value in the pore liquid (gas) that fill the pores of the mine rock, we will solve the inequations (19) with respect to the pore pressure $P$. We have:

$$
\begin{gathered}
\xi=\frac{R_{p}}{R_{c}} ; \\
\sigma_{1} \leq R_{c}-\frac{1-\xi}{\xi} \cdot P \\
\sigma_{1} \geq 2 P-2 R_{c} \cdot \frac{\xi}{1-\xi} \\
\sigma_{1} \geq \sigma_{2} \geq \sigma_{3} .
\end{gathered}
$$

It should be noted, that the ratios (32) are completely analogous to (25). The only difference between them is in the material constants.

Further on, we will find the dependence of the critical (destructive) principal stress $\sigma_{1}=q+\gamma$ on the pore pressure $P$ in the coal seam (see the computational scheme in Figure 1).

So, for example, if the compressive strengths are $R_{c}=10.8 \mathrm{MPa}$ and the tensile strength is $R_{p}=0.84 \mathrm{MPa}$, then from (19), with account of these values, we will get:

$$
\left.\begin{array}{c}
\xi=0.078 \\
\sigma_{1} \leq 10.8-11.86 P \\
\sigma_{1} \geq 2 P-1.82 \\
\sigma_{1} \geq \sigma_{2} \geq \sigma_{3}
\end{array}\right\}
$$

The graphical interpretation (33) is represented in Figure 6. It follows from the figure, that at zero pore pressure the critical value of the principal stress $\sigma_{1}$ is equal to $11 \mathrm{MPa}$. With an average bulk density of $20 \mathrm{kN} / \mathrm{m}^{3}$, this pressure corresponds to a depth of 550 meters.

Explanatory notes:

1. The area is marked with a gray color in which the values are located of the principal stress $\sigma_{1}$ and the pore pressure $P$ in the coal seam, corresponding to the stable state of the mine working.

2. Black solid lines indicate the boundaries of the stable zone of the mine working.

At a pore liquid (or gas) pressure equal to $P=0.6 \mathrm{MPa}$ or (6 atmospheres), the critical value of the principal stress $\sigma_{1}$ is $3.7 \mathrm{MPa}$. With an average value of the bulk density of $20 \mathrm{kN} / \mathrm{m}^{3}$, this pressure corresponds to a depth of 185 meters.

Thus, the presence of excess pressure in the coal seam resulted in a decrease in the depth of the mine working drivage without support from 550 to 185 meters.

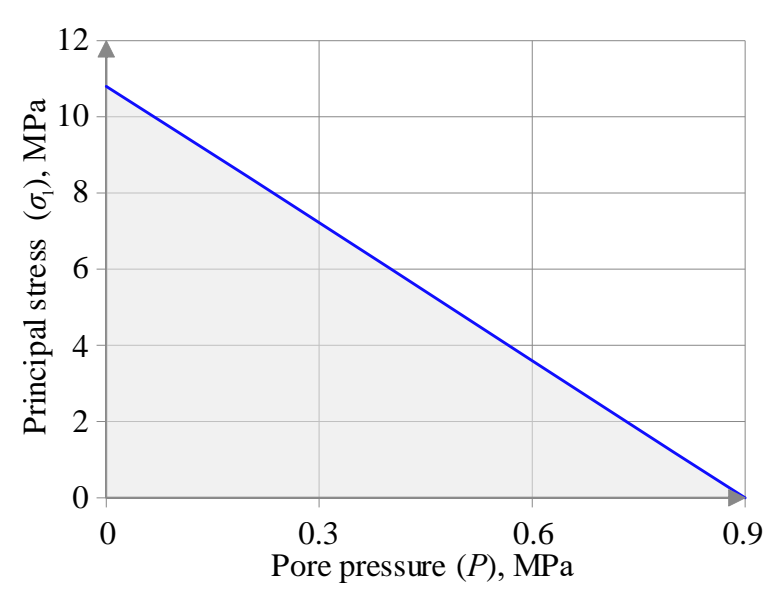

Figure 6. The dependence of the principal stress $\sigma_{1}$ on the pore pressure $P$ in the coal seam

Herewith, with account of the coefficient $k_{c}$ of structural weakening, the value of which, for example, is 0.3 , the value of the ultimate depths will be 165 and $55.5 \mathrm{~m}$, respectively.

\section{Conclusions}

In general, the research materials presented in this article made it possible to draw such conclusions:

1. A generalization has been performed of the known one-dimensional Mohr-Coulomb strength condition for a water-saturated base characterized by the strength characteristics $c$ and $\varphi$ to the dimensional case. With this, the same result has been obtained in two completely different ways.

2 . These results have been generalized to the case of water-saturated and water-free mine rock, characterized by strength characteristics $R_{c}$ and $R_{p}$.

3 . The difference of these strength criteria from analogous ones for water-free soils and mine rocks is their ambiguity:

3.1. For a water-free soil (or mine rock), we have only one critical point, separating the area in which the strength of the soil (or mine rock) is protected from the area in which destruction occurs.

3.2. For water-saturated soils (or mine rocks), we have two critical points instead of one. The first point separates the area, in which the strength of the soil (or mine rock) is protected from the area in which the obtained strength criteria (3) and (11) are not applicable. With this, the second point separates the area in which the strength of the soil (or mine rock) is protected from the area in which the destruction occurs.

4. An analytical solution has been obtained for the problem of determining the critical vertical pressure at which the vertical walls of mine workings and vertical water-saturated slopes are destroyed.

5. The obtained results make it possible to solve such practical problems:

5.1. The stability determination of water-saturated slopes and side-hills with a load-free daylight surface.

5.2. The stability determination of water-saturated slopes and side-hills on the daylight surface of which there is a load (including the weight of the equipment, stored material and the ground, mined during extraction, etc.).

5.3. The assessment of the vertical walls stability of water-saturated seams of mine workings (including the walls of mine shafts and pit walls).

5.4. The assessment of the vertical walls stability of water-saturated coal seams during mine workings drivage. 


\section{Acknowledgements}

The results presented in the paper has been obtained without the financial support of any grant or a scientific project. The writing team expresses gratitude to the reviewers for the valuable recommendations that have been taken into account to significantly improve the quality of this paper.

\section{References}

[1] Pivnyak, G.G., \& Shashenko, O.M. (2015). Innovations and safety for coal mines in Ukraine. Naukovyi Visnyk Natsionalnoho Hirnychoho Universytetu, (6), 118-121.

[2] Petlovanyi, M.V., Lozynskyi, V.H., Saik, P.B., \& Sai, K.S. (2018). Modern experience of low-coal seams underground mining in Ukraine. International Journal of Mining Science and Technology, 28(6), 917-923. https://doi.org/10.1016/j.ijmst.2018.05.014

[3] Rana, M.S., \& Al Humaidan, F.S. (2015). Statistical data on worldwide coal reserves, production, consumption, and future demand. Coal Production and Processing Technology, 31-50 https://doi.org/10.1201/b19352

[4] Sribna, Y., Trokhymets, O., Nosatov, I., \& Kriukova, I. (2019). The globalization of the world coal market - contradictionns and trends. E3S Web of Conferences, (123), 01044. https://doi.org/10.1051/e3sconf/201912301044

[5] Medunić, G., Mondol, D., Rađenović, A., \& Nazir, S. (2018). Review of the latest research on coal, environment, and clean technologies. Rudarsko Geolosko Naftni Zbornik, 33(3), 13-21. https://doi.org/10.17794/rgn.2018.3.2

[6] Teng, J., Qiao, Y., \& Song, P. (2016). Analysis of exploration, potential reserves and high efficient utilization of coal in China. Acta Geophysica Sinica, 59(12), 4633-4653.

[7] Feng, X. (2017). Rock mechanics and engineering. Volume 5. https://doi.org/10.4324/9781315708119

[8] Peng, S.S. (2017). Advances in coal mine ground control. https://doi.org/10.1016/b978-0-08-101225-3.00023-2

[9] Symanovych, G., Demydov, M., \& Chervatuk, V. (2013). Influence mechanism of rock mass structure forming a stress on a face support. Annual Scientific-Technical Collection - Mining of Mineral Deposits, 77-81. https://doi.org/10.1201/b16354-14

[10] Li, C.C. (2017). Rockbolting: Principles and applications. Oxford, United Kingdom: Elsiver.

[11] Shashenko, O.M., Sdvyzhkova, O.O., \& Hapieiev, S.M. (2008). Deformovanist ta mitsnist masyviv hirskykh porid. Dnipropetrovsk, Ukraina: Natsionalnyi hirnychyi universytet.

[12] Shapoval, A.V., \& Shapoval, V.G. (2009). Teoriya vzaimosvyazannoy fil'tratsionnoy konsolidatsii. Dnepropetrovsk, Ukraina: Porogi.

[13] Czapliński, A., \& Hołda, S. (1982). Changes in mechanical properties of coal due to sorption of carbon dioxide vapour. Fuel, 61(12), 1281-1282. https://doi.org/10.1016/00162361(82)90035-7

[14] Entov, V.M., \& Malakhova, T.A. (1974). Changes in the strain-stressed state of rock bodies following changes of pressure in a liquid-saturated stratum. Mekh Tverd Tela, (6), 53-65.

[15] Galiev, S.Z., Galiev, D.A., Seitaev, E.N., \& Uteshov, E.T. (2019). Unified methodology for management of a geotechnological complex in open pit mining. Gornyi Zhurnal, (12), 7075. https://doi.org/10.17580/gzh.2019.12.15

[16] Liu, Z., Yang, H., Wang, W., Cheng, W., \& Xin, L. (2018). Experimental study on the pore structure fractals and seepage characteristics of a coal sample around a borehole in coal seam water infusion. Transport in Porous Media, 125(2), 289-309. https://doi.org/10.1007/s11242-018-1119-x

[17] Zhu, J. (2018). Coal pore characteristics in different coal mine dynamic disasters. Arabian Journal of Geosciences, 11(17). https://doi.org/10.1007/s12517-018-3859-x

[18] Sdvizhkova, Ye.A., Babets, D.V., \& Smirnov, A.V. (2014). Support loading of assembly chamber in terms of western Donbas plough longwall. Naukovyi Visnyk Natsionalnoho Hirnychoho Universytetu, (5), 26-32.
[19] Piwniak, G.G., Bondarenko, V.I., Salli, V.I., Pavlenko, I.I., \& Dychkovskiy, R.O. (2007). Limits to economic viability of extraction of thin coal seams in Ukraine. Technical, Technological and Economic Aspects of Thin-Seams Coal Mining, 129132. https://doi.org/10.1201/noe0415436700.ch16

[20] Lozynskyi, V., Saik, P., Petlovanyi, M., Sai, K., \& Malanchuk, Y. (2018). Analytical research of the stress-deformed state in the rock massif around faulting. International Journal of Engineering Research in Africa, (35), 77-88. https://doi.org/10.4028/www.scientific.net/jera.35.77

[21] Abisheva, Z.S., Karshigina, Z.B., Bochevskaya, Y.G., Akcil, A., Sargelova, E.A., Kvyatkovskaya, M.N., \& Silachyov, I.Y. (2017). Recovery of rare earth metals as critical raw materials from phosphorus slag of long-term storage. Hydrometallurgy, (173), 271-282. https://doi.org/10.1016/j.hydromet.2017.08.022

[22] Khomenko, O.Ye., Sudakov, A.K., Malanchuk, Z.R., \& Malanchuk, Ye.Z. (2017). Principles of rock pressure energy usage during underground mining of deposits. Naukovyi Visnyk Natsionalnoho Hirnychoho Universytetu, 2(158), 34-43.

[23] Pivnyak, G., Dychkovskyi, R., Bobyliov, O., Cabana, E.C., \& Smoliński, A. (2018). Mathematical and geomechanical model in physical and chemical processes of underground coal gasification. Solid State Phenomena, (277), 1-16. https://doi.org/10.4028/www.scientific.net/ssp.277.1

[24] Abisheva, Z.S., Bochevskaya, E.G., Zagorodnyaya, A.N., Shabanova, T.A., \& Karshigina, Z.B. (2013). Technology of phosphorus slag processing for preparation of precipitated silica. Theoretical Foundations of Chemical Engineering, 47(4), 428-434. https://doi.org/10.1134/s0040579513040027

[25] Menshov, O., Kuderavets, R., Popov, S., Homenko, R., Sukhorada, A., \& Chobotok, I. (2016). Thermomagnetic analyzes of soils from the hydrocarbon fields. Visnyk of Taras Shevchenko National University of Kyiv. Geology, 73(2), 3337. https://doi.org/10.17721/1728-2713.79.05

[26] Reznik, A.M., Rozen, A.M., Abisheva, Z.S. (1976). Effect of organic-solvents on cesium extraction by para-alkylphenols. Zhurnal Neogranicheskoi Khimii, 21(4), 1140-1142.

[27] Bulat, A.F., Mineev, S.P., Bryukhanov, A.M., \& Nikiforov, A.V. (2013). Development of classification procedure for gas-dynamic events in coal mines. Journal of Mining Science, 49(6), 894-901. https://doi.org/10.1134/S1062739149060075

[28] Mineev, S.P., \& Prusova, A.A. (1992). Kinetics of the structural changes in the counterpressure zone of a stressed gassaturated coal bed. Journal of Mining Science, 28(2), 150-156. https://doi.org/10.1007/BF00710734

[29] Bulat, A.F., Mineev, S.P., \& Prusova, A.A. (2016). Generating methane adsorption under relaxation of molecular structure of coal. Journal of Mining Science, 52(1), 70-77. https://doi.org/10.1134/S1062739116010149

[30] Bondarenko, V.I., Kharin, Ye.N., Antoshchenko, N.I., \& Gasyuk, R.L. (2013). Basic scientific positions of forecast of the dynamics of methane release when mining the gas bearing coal seams. Naukovyi Visnyk Natsionalnoho Hirnychoho Universytetu, (5), 24-30.

[31] Bondarenko, V., Kovalevs'ka, I., \& Ganushevych, K. (2014). Progressive technologies of coal, coalbed methane, and ores mining. London, United Kingdom: CRC Press, Taylor \& Francis Group. https://doi.org/10.1201/b17547

[32] Sobolev, V.V., Bilan, N.V., \& Khalymendyk, A.V. (2017). On formation of electrically conductive phases under electrothermal activation of ferruginous carbonates. Naukovyi Visnyk Natsionalnoho Hirnychoho Universytetu, (4), 27-36.

[33] Sobolev, V.V., \& Usherenko, S.M. (2006). Shock-wave initiation of nuclear transmutation of chemical elements. Journal de Physique IV (Proceedings), (134), 977-982. https://doi.org/10.1051/jp4:2006134149

[34] Chernai, A.V., Sobolev, V.V., Chernai, V.A., Ilyushin, M.A., \& Dlugashek, A. (2003). Laser ignition of explosive compositions based on di-(3-hydrazino-4-amino-1,2,3-triazole)copper (II) perchlorate. Combustion, Explosion and Shock Waves, 39(3), 335-339. 
[35] Babets, D. (2018). Rock mass strength estimation using structural factor based on statistical strength theory. Solid State Phenomena, 277, 111-122. https://doi.org/10.4028/www.scientific.net/ssp.277.111

[36] Solodyankin, O., \& Ruban, N. (2014). Influence of the dynamic loading on stress-strain state of subsiding soils under buildings and structures. Progressive Technologies of Coal, Coalbed Methane, and Ores Mining, 395-400. https://doi.org/10.1201/b17547-67

[37] Shapoval, V.G., Sedin, V.L., Shapoval, A.V., Morklyanik, B.V., \& Andreev, V.S. (2010). Mehanika gruntov. Dnepropetrovsk, Ukraina: Porogi.

[38] Shashenko, A.N., Tulub, S.B., \& Sdvizhkova, E.A. (2002). Nekotoryie zadachi statisticheskoy geomehaniki. Kiev, Ukraina.

[39] Uhov, S.B. (2007). Mehanika gruntov, osnovaniya i fundamentyi. Moskva, Rossiya: ASV.
[40] Shashenko, O., Shapoval, V., Khalymendyk, O., Andrieiev, V., Arbuzov, M., Hubar, O., \& Markul, R. (2019). Features of the nonlinear calculation of the stress-strain state of the "Rock massif-excavation support" system taking into account destructtion. Transport Means, 1356-1363.

[41] Shashenko, O.M., Hapieiev, S.M., Shapoval, V.G., Khalymendyk, O.V. (2019). Analysis of calculation models while solving geomechanical problems in elastic approach. Naukovyi Visnyk Natsionalnoho Hirnychoho Universytetu, (1), 28-36. https://doi.org/10.29202/nvngu/20191/21

[42] Shashenko, A., Gapieiev, S., \& Solodyankin, A. (2009). Numerical simulation of the elastic-plastic state of rock mass around horizontal workings. Archives of Mining Sciences, 54(2), 341-348.

\section{Оцінка стійкості укосів і схилів з урахуванням надлишкового тиску в поровій рідині}

\section{В. Шаповал, О. Шашенко, С. Гапєєв, О. Халимендик, В. Андрєєв}

Мета. Обгрунтування критеріїв міцності водонасичених грунтів і гірських порід, що дозволяють отримувати аналітичні рішення, необхідні для визначення стійкості обводнених грунтових укосів та схилів.

Методика. Застосовано методи аналізу та узагальнення результатів теоретичних і чисельних експериментальних досліджень. Враховано характеристики порід і грунтів: питоме зчеплення $c$, кут внутрішнього тертя $\varphi$, міцність породи на стиск $R_{c}$ і розтяг $R_{p}$, питому вагу. До покрівлі водонасиченого шару прикладалася навантаження $q$ від верхніх шарів порід (грунту), ваги розташованого на поверхні обладнання або конструкцій. Прийнято, що шар насичений водою (газом) з надлишковим тиском $P$. Розглядається точка на поверхні виробки (або вертикального укосу), розташована на глибині $z$. Визначається, при якому співвідношенні параметрів $q, P$ i $z$ відбудеться руйнування грунтового або породного шару. Рішення завдання здійснюється на підставі критерію міцності Мора-Кулона.

Результати. Проведено зіставлення міцності водо- і неводонасиченої породи. Отримані співвідношення дозволяють визначити критичне навантаження на денну поверхню водонасичених і неводонасищенних вертикальних укосів, схилів, траншей та котлованів, а також інших виробок у грунтових основах і гірських породах. Отримано аналітичний розв'язок, що дозволяє визначати величину критичного тиску на обводнені вертикальні поверхні та грунтові відкоси. Виконано узагальнення відомої одновимірної умови міцності Мора-Кулона для водонасиченої основи, що характеризується міцністю $c$ і $\varphi$ на просторовий випадок.

Наукова новизна. Теоретично доведено, що при будь-якому значенні порового тиску у водонасиченій гірській породі (або грунті) їх міцність буде менше, ніж у неводонасиченному стані. Сформульовано нові рішення задач із визначення критичної висоти водонасиченого вертикального грунтового укосу або стінки вертикальної гірничої виробки.

Практичне значення. Отримані результати дозволяють вирішувати практичні інженерні завдання з визначення стійкості водонасичених укосів і схилів з вільною від навантаження денною поверхнею і з урахуванням ваги обладнання, складованих матеріалів і стійкості вертикальних стінок водонасичених шарів відкритих виробок.

Ключові слова: критерій міцності, порова рідина, поровий газ, тиск, стійкість укосу, кут тертя

\section{Оценка устойчивости откосов и склонов с учетом избыточного давления в поровой жидкости}

\section{В. Шаповал, А. Шашенко, С. Гапеевв, А Халимендик, В. Андреев}

Цель. Обоснование критериев прочности водонасыщенных грунтов и горных пород, позволяющие получать аналитические решения, необходимые для определения устойчивости обводненных грунтовых откосов и склонов.

Методика. Применены методы анализа и обобщения результатов теоретических и численных экспериментальных исследований. Учтены характеристики пород и грунтов: удельное сцепление $c$, угол внутреннего трения $\varphi$, прочность породы на сжатие $R_{c}$ и растяжение $R_{p}$, удельный вес. К кровле водонасыщенного слоя прикладывалась нагрузка $q$ от вышележащих слоев пород или грунта, веса расположенного на поверхности оборудования или конструкций. Принято, что слой насыщен водой (газом) с избыточным давлением $P$. Рассматривается точка на поверхности выработки (или вертикального откоса), расположенная на глубине $z$. Определяется, при каком соотношении параметров $q, P$ и $z$ произойдет разрушение грунтового или породного слоя. Решение задачи осуществляется на основании критерия прочности Мора-Кулона.

Результаты. Проведено сопоставление прочности водо- и неводонасыщенной породы. Получены соотношения позволяющие определить критическую нагрузку на дневную поверхность водонасыщенных и неводонасыщенных вертикальных откосов, склонов, траншей и котлованов, а также прочих выработок в грунтовых основаниях и горных породах. Получено аналитическое решение, позволяющее определять величину критического давления на обводненные вертикальные поверхности и грунтовые откосы. Выполнено обобщение известного одномерного условия прочности Мора-Кулона для водонасыщенного основания, характеризующегося прочностными характеристиками $c$ и $\varphi$ на пространственный случай.

Научная новизна. Теоретически доказано, что при любом значении порового давления в водонасыщенной горной породе (или грунте) их прочность будет меньше, чем в неводонасыщенном состоянии. Сформулированы новые решения задач по определению критической высоты водонасыщенного вертикального грунтового откоса или стенки вертикальной горной выработки.

Практическое значение. Полученные результаты позволяют решать практические инженерные задачи по определению устойчивости водонасыщенных откосов и склонов со свободной от нагрузки дневной поверхностью и с учетом веса оборудования, складированных материалов и устойчивости вертикальных стенок водонасыщенных слоев открытых выработок.

Ключевые слова: критерий прочности, поровая жидкость, поровый газ, давление, устойчивость откоса; угол трения

\section{Article info}

Received: 4 February 2019

Accepted: 12 February 2020

Available online: 5 March 2020 